\title{
Immunochemical recognition of phytoplankton species
}

\author{
Lynda P. Shapiro ${ }^{1}$, Lisa Campbell ${ }^{2}$, Elin M. Haugen ${ }^{1}$ \\ ' Bigelow Laboratory for Ocean Sciences, McKown Point, West Boothbay Harbor, Maine 04575, USA \\ ${ }^{2}$ Hawaii Institute of Geophysics, University of Hawaii, Honolulu, Hawaii 96822, USA
}

\begin{abstract}
A.BSTRACT. We have developed polyclonal antisera to phytoplankton species from most major groups of ultraplankton taxa. Surface antigens were provided by 7 clonal cultures of cells from 6 major algal groups. The resulting antisera were tested rigorously in an indirect immunofluorescence (IF) assay, for cross reactions against closely and more distantly related taxa in order to determine levels of specificity of the responses. For each of the antigens, we obtained an antiserum that was at least genus-specific; most were species-specific (within the limits of known species identifications). Within species, clones isolated from widely different geographic and ecological origins all cross reacted. In the one species where life history stages were tested (Emiliania huxleyi) both the flagellated and the non-motile stages reacted. The IF approach will allow identification of very small species and the quantification of specific components in the natural community and thus will permit studies of spatial and temporal changes in dominance and diversity within the ultraplankton community.
\end{abstract}

\section{INTRODUCTION}

The advent of epifluorescence microscopy and its application to analysis of marine phytoplankton samples (Hobbie et al. 1977) has provided the means for making the minute cells of ultraplankton visible and clearly distinguishable from debris. It quickly became obvious that while the bulk of photosynthetic ultraplankton are phycoerythrin-rich cyanobacteria (Johnson \& Sieburth 1979, Waterbury et al. 1979), at certain times and under certain conditions, that size fraction is dominated by minute eukaryotes (Johnson \& Sieburth 1982, Davis et al. 1985, Murphy \& Haugen 1985).

The eukaryotic component is diverse and contains representatives of most phytoplankton classes (Shapiro \& Guillard 1986, Stockner \& Antia 1986, Thomsen 1986). Electron micrographs of natural assemblages show many different types of cells and representatives of 9 classes have been cultured. We have tested preservative effects on clonal cultures and determined that many ultraplankters explode or lyse in preservative solutions, while others are relatively impervious to fixation so that internal details become distorted enough to limit resolution of taxonomic features. Prasinophytes and cryptomonads are most vulnerable. Electron microscopy (EM), thus, gives neither reliable quantitative nor qualitative determinations of the various ultraplankton taxa. Similarly, culture techniques may not yield good estimates of relative abundances since culturable types are not necessarily a random sample of the natural assemblage. Thus, although we know the assemblage is diverse, we have no knowledge of the relative contribution of the different taxa.

Since even species or genotypes can respond differently to environmental changes and provide different food potential to higher trophic levels, knowledge of taxonomic composition is essential. It seemed to us that the best initial approach to identifying and tracing the various ultrapiankton components would be an immunological assay (Campbell et al. 1983). We sought to develop antibodies directed against cell surface antigens of specific ultraplankton taxa and use them in an immunofluorescence (IF) assay, in order to trace the relative abundances of the different taxa in natural assemblages.

\section{MATERIALS AND METHODS}

Seven clonal cultures of cells representing 6 major algal groups were selected as antigens (Table 1). Within the class Micromonadophyceae (Mattox \& 
Table 1 Clones used as antigen

\begin{tabular}{|c|c|c|}
\hline Class & Species & Clone \\
\hline Bacillariophyceae & Thalassiosira oceanica & $13-1$ \\
\hline Chrysophyceae & Pelagococcus subviridis & PELA CL2 \\
\hline Cr:ptophyceae & Chroomonas salina & $3 \mathrm{C}$ \\
\hline \multirow[t]{2}{*}{ Nicromonadophyceae } & Unidentified coccoid & $\Omega 48-23$ \\
\hline & Micromonas pusilla & DW8 \\
\hline Prymnesiophyceae & Emiliania huxleyi & $B T-6$ \\
\hline Chlorophyceae & Dunaliella tertiolecta & DUN \\
\hline
\end{tabular}

Stewart 1984), 2 common marine cell types, a coccoid form ( $\Omega 48-23$ ) and a flagellated form (DW-8) were used as antigens.
Methods for antibody production were according to Campbell et al. (1989). Briefly, polyclonal antisera, directed against cell surface antigens of whole cells, were produced in rabbits. Test bleeds were analyzed for antibody activity using an IF assay (Campbell 1988) with a secondary, fluorescein isothiocyanate (FITC)conjugated, swine anti-rabbit antibody. Titers were determined using a series of 2 -fold dilutions of each antiserum in phosphate-buffered saline (PBS), and rated for the visual quality of staining $(4+=$ bright stain, $95 \%$ of cells stained; $3+=$ less bright, 80 to $90 \%$ stained; $2+=$ low intensity stain, but obvious compared to control, $50 \%$ or more stained; $1+=$ low intensity, but separable from control, 10 to $50 \%$ of cells

Table 2. Cross reactions among major groups. +: Positive reaction between antiserum and test clone; -: no reaction. For clone identification see Table 1

\begin{tabular}{|c|c|c|c|c|c|c|c|}
\hline \multirow[t]{2}{*}{ Clone } & \multicolumn{7}{|c|}{ Antisera directed against clone } \\
\hline & $13-1$ & DUN & PELA CL2 & $3 C$ & $\Omega 48-23$ & $\mathrm{DW}-8$ & BT6 \\
\hline \multicolumn{8}{|l|}{ BACILLARIOPHYCEAE } \\
\hline $\begin{array}{l}\text { Thalassiosira oceanica } \\
(13-1)\end{array}$ & + & - & - & - & -- & - & -- \\
\hline $\begin{array}{l}\text { Cylindrotheca closterium } \\
\text { (WT5) }\end{array}$ & - & - & - & - & - & - & - \\
\hline \multicolumn{8}{|l|}{ CHLOROPHYCEAE } \\
\hline $\begin{array}{l}\text { Dunaliella tertiolecta } \\
\text { (DUN) }\end{array}$ & - & + & - & - & - & - & - \\
\hline \multicolumn{8}{|l|}{ CHRYSOPHYCEAE } \\
\hline $\begin{array}{l}\text { Pelagococcus subviridis } \\
\text { (PELA CL2) }\end{array}$ & - & - & + & - & - & - & -- \\
\hline $\begin{array}{l}\text { Aureococcus anophagefferens } \\
\text { (b.t.1) }\end{array}$ & - & - & - & - & - & - & - \\
\hline \multicolumn{8}{|l|}{ CRYPTOPHYCEAE } \\
\hline $\begin{array}{l}\text { Chroomonas salina } \\
(3 \mathrm{C})\end{array}$ & - & - & - & + & - & - & - \\
\hline \multicolumn{8}{|l|}{ CYANOBACTERIA } \\
\hline Synechococcus (WH7803) & - & - & - & -- & - & - & - \\
\hline (WH5701) & - & - & - & - & - & - & - \\
\hline \multicolumn{8}{|l|}{ DINOPHYCEAE } \\
\hline $\begin{array}{l}\text { Alexandrium (Gonyaulax) tamarensis } \\
\text { (GT429) }\end{array}$ & - & - & - & - & - & - & - \\
\hline $\begin{array}{l}\text { Gyrodinium sp. } \\
(94 \text { GYR })\end{array}$ & - & - & - & - & - & - & - \\
\hline \multicolumn{8}{|l|}{ EUSTIGMATOPHYCEAE } \\
\hline $\begin{array}{l}\text { Nannochloropsis salina } \\
\text { (GSB Sticho) }\end{array}$ & - & - & - & - & - & - & - \\
\hline $\begin{array}{l}\text { Nannochloropsis sp. } \\
(7-15 \text { Sticho })\end{array}$ & - & - & - & - & - & - & - \\
\hline \multicolumn{8}{|l|}{ MICROMONADOPHYCEAE } \\
\hline $\begin{array}{l}\text { Unidentified coccoid } \\
(\Omega 48-23)\end{array}$ & - & - & - & - & + & - & - \\
\hline $\begin{array}{l}\text { Micromonas pusilla } \\
\text { (DW-8) }\end{array}$ & - & - & - & - & - & + & - \\
\hline \multicolumn{8}{|l|}{ PRYMNESIOPHYCEAE } \\
\hline $\begin{array}{l}\text { Emiliania huxleyi } \\
\text { (BT-6) }\end{array}$ & - & - & - & - & - & - & + \\
\hline
\end{tabular}


stained). All tests (experimental and control) were read 'blind', i.e the person reading and scoring the tests did not know the identity of the tested material. All samples were examined with a Zeiss Axiomat epifluorescence microscope equipped with a $50 \mathrm{~W}$ mercury lamp and Zeiss filter set \#48-77-09 blue excitation (BP450490) and emission cutoff at $520 \mathrm{~nm}$ for FITC fluorescence.

In initial tests with glutaraldehyde-preserved cells, we experienced aldehyde-induced fluorescence that increased with cell storage time and interfered with the IF assay. Additionally, the excellent cross-linking properties of glutaraldehyde produced many false positives. Thus, paraformaldehyde, pH 7.4, was used exclusively in all subsequent tests. For most cell types, analysis of preserved samples was best completed within $4 \mathrm{~h}$ since preservation was not reliable for longer periods.

To determine the specificity of each antiserum, we tested for cross reactions, i.e., reactions with clones not present in the immunization preparation. We tested representatives of 9 major phytoplankton groups (Table 2) which, in addition to the 7 clones in 6 classes used as antigens, included cyanobacteria, Dinophyceae and Eustigmatophyceae. Within each algal group, we further tested representative coastal and oceanic clones of conspecific, congeneric and unrelated genera (Tables 3 to 8). All antisera were compared to preimmunization sera controls to rule out non-specific binding (false positives)

\section{RESULTS}

For each of the antigens we obtained an antiserum that was at least genus-specific, i.e. it did not cross react with strains outside of the genus. Within the Bacillariophyceae, 3 of 4 Thalassiosira clones cross reacted with anti-13-1 ( $T$. oceanica). Of these, one was 13-1 itself, and one was a clone of the very closelyrelated species, T. pseudonana. These 2 species appear to be capable of genetic recombination (Brand et al. 1981), and have been considered ecological races of the same species (Murphy \& Guillard 1976). The third cross-reactive clone was a congeneric clone that has not been identified to species. None of the clones from 5 other diatom genera cross reacted with 13-1 (Table 3).

Within the Prymnesiophyceae, representatives of 7 genera were screened with antiserum directed against naked cells of the cosmopolitan species Emiliania huxleyj (anti-BT6). This antiserum was species-specific (Table 4). All tested clones of E. huxleyi showed clear cross-reactions even though these clones were isolated from a broad geographic and ecological range (Gulf of Maine, clone 8613; Oslofjord, clone 451B; British coastal waters, clones $92 \mathrm{~A}$ and $92 \mathrm{D}$; Sargasso Sea, clones
Table 3. Cross reactions within the Bacillariophyceae with antiserum directed against Thalassiosira oceanica (13-1). Reaction $=$ rating for visual quality of staining. $4+$. bright stain, $95 \%$ of cells stained, $3+$ : less bright, 80 to $90 \%$ stained: $2+$ : low intensity stain, but obvious compared to control, $50+$ $\%$ stained; $1+$ : low intensity, but separable from control, 10 to $50 \%$ stained; - : no reaction

\begin{tabular}{|lll|}
\hline Clone & Designation & Reaction \\
\hline Thalassiosira & & \\
oceanica & $13-1$ & $3+$ \\
pseudonand & $3 \mathrm{H}$ & $3+$ \\
sp. & CHB51 & $3+$ \\
weissflogii & $4 \mathrm{C}$ & - \\
Chaetoceros & & \\
gracile & SOLCHAET & - \\
gracile & WTAX1 & - \\
Minutocellus & & - \\
polymorphus & SAY7 & - \\
polymorphus & BCN & - \\
Cylindrotheca & & - \\
closterium & WT5 & \\
Nitzschia sp. & $9-9 \mathrm{a}$ & \\
\hline
\end{tabular}

Table 4. Cross reactions within the Prymnesiophyceae with antiserum directed against Emiliania huxleyi (BT-6). Reaction: see legend Table 3

\begin{tabular}{|c|c|c|}
\hline Clone & Designation & Reaction \\
\hline Emiliania huxleyi & $\begin{array}{l}\text { BT-6 (naked) } \\
\text { MCH1 (naked) } \\
8613 \text { (lith-bearing) } \\
451 \mathrm{~B} \text { (naked) } \\
\text { 92A (scaled/motile) } \\
\text { 92D (lith-bearing) }\end{array}$ & $\begin{array}{l}4+ \\
1+ \\
3+ \\
4+ \\
3+ \\
3+\end{array}$ \\
\hline $\begin{array}{l}\text { Chrysochromulina } \\
\text { ericina } \\
\text { herdlansis }\end{array}$ & $\begin{array}{l}\text { NEPCC } 109 A \\
\text { NEPCC } 186\end{array}$ & $\begin{array}{l}- \\
-\end{array}$ \\
\hline $\begin{array}{c}\text { Coccolithus } \\
\text { carterae } \\
\text { neohelis } \\
\text { pelagicus }\end{array}$ & $\begin{array}{l}265-04 \\
\text { CONE } \\
\text { COPEL }\end{array}$ & $\begin{array}{l}- \\
- \\
-\end{array}$ \\
\hline $\begin{array}{r}\text { Imantonia } \\
\text { rotunda } \\
\text { rotunda }\end{array}$ & $\begin{array}{l}\text { WTRE } \\
\text { IIE.6 }\end{array}$ & $\begin{array}{l}- \\
-\end{array}$ \\
\hline $\begin{array}{l}\text { Pavlova } \\
\text { lutheri } \\
\text { pingus }\end{array}$ & $\begin{array}{l}\text { MONO } \\
\text { IG7 }\end{array}$ & $\begin{array}{l}- \\
-\end{array}$ \\
\hline $\begin{array}{l}\text { Phaeocystis } \\
\text { sp. }\end{array}$ & 1209 & - \\
\hline $\begin{array}{l}\text { Pleurochrysis } \\
\text { carterae }\end{array}$ & coccoll & - \\
\hline
\end{tabular}

BT-6 and MCH1). Positive tests included strains of $E$. huxleyi that were 'naked' (BT-6, MCH1 and 451B), coccolith-bearing (92D and 8613), and 1 motile, scaled strain (92A). 
Table 5. Cross reactions within the Micromonadophyceae and related prasinophytes with antisera directed against $\mathrm{Mi}$ cromonas pusilla (DW-8) and an unidentified coccoid clone $(\Omega 48-23)$. Reaction: see legend Table 3

\begin{tabular}{|c|c|c|c|}
\hline \multirow[t]{2}{*}{ Clone } & \multirow[t]{2}{*}{ Designation } & \multicolumn{2}{|c|}{ Reactions } \\
\hline & & DW -8 & $\Omega 48-23$ \\
\hline \multirow[t]{4}{*}{ Coccoids } & $\Omega 48-23$ & - & $4+$ \\
\hline & $1326-01$ & - & $4+$ \\
\hline & $1201-2$ & - & $4+$ \\
\hline & BT5 & - & $4+$ \\
\hline \multicolumn{4}{|l|}{ Micromonas } \\
\hline pusilla & DW-8 & $4+$ & - \\
\hline pusilla & IIE1 & $3+$ & - \\
\hline pusilla & IVO3 & $1+$ & - \\
\hline pusilla & PLY27 & $1+$ & - \\
\hline \multicolumn{4}{|l|}{ Unidentified } \\
\hline flagellate & IB4 & - & - \\
\hline \multicolumn{4}{|l|}{ Mantoniella } \\
\hline squamata & PLY189 & - & - \\
\hline \multicolumn{4}{|l|}{ Nephroselmis } \\
\hline pyriformis & UW460 & - & - \\
\hline \multicolumn{4}{|l|}{ Pedinomonas } \\
\hline minutissima & VA3 & - & - \\
\hline \multicolumn{4}{|l|}{ Pseudoscorfielda } \\
\hline marina & IVP11. & - & - \\
\hline \multicolumn{4}{|l|}{ Pyramimonas } \\
\hline grossii & PLY78 & - & - \\
\hline \multicolumn{4}{|l|}{ Tetraselmis } \\
\hline carteriiformis & UW439 & - & - \\
\hline sp. & REY2 & - & - \\
\hline
\end{tabular}

Similarly, results with antiserum directed against the cosmopolitan micromonadophyte Micromonas pusilla (anti-DW-8) were species-specific (Table 5). Four conspecific clones reacted, those from Woods Hole, Mass. (DW-8), slope waters of the Northwest Atlantic (IIE1), the Gulf of Mexico (IV03) and Plymouth, England (PLY27). A fifth unidentified clone, IB4, did not cross react. This clone superficially resembles Micromonas, but is even smaller. Antiserum cirected against the coccoid micromonadophyte (anti- $248-23$ ) was specific to the morphological type (Table 5), and consistent with chemotaxonomic groupings based on pigment types (Hooks et al. 1988, Shapiro et al. 1989).

An antiserum directed against the cryptophyte Chroomonas salina (anti-3C) (Table6) was at least genus-specific, and possibly species-specific. However, a second rabbit produced a more general antiserum that, although at least class-specific, cross reacted with at least 3 different genera.

Antiserum directed against the chlorophyte Dunaliella tertiolecta (anti-DUN) cross reacted with itself and with $D$. parva clone KGDUN which may be closely related (Butcher 1959), but not with $D$. viridis.
Table 6 . Cross reactions within the Cryptophyceae with antisera directed against Chroomonas salina (3C). Reaction: see legend Table 3

\begin{tabular}{|lclc|}
\hline Clone & Rabbit & Designation & Reaction \\
\hline Chroomonas salina & 1 & $3 \mathrm{C}$ & $4+$ \\
Rhodomonas sp. & 2 & & $4+$ \\
& 1 & WT651/60 & - \\
Rhodomonas lens & 2 & & $4+$ \\
Cryptomonas sp. & 1 & RLENS & - \\
Cryptomonas sp. & 2 & & $2+$ \\
& 1 & ID2 & - \\
Two rabbits were challenged with the same antigen & \\
\hline
\end{tabular}

Table 7 . Cross reactions within the Chlorophyceae antiserum directed against Dunaliella tertiolecta (DUN). Reaction: see legend Table 3

\begin{tabular}{|lll|}
\hline Clone & Designation & Reaction \\
\hline $\begin{array}{l}\text { Dunaliella } \\
\text { tertiolecta }\end{array}$ & DUN & \\
$\begin{array}{l}\text { parva } \\
\text { viridis }\end{array}$ & KG DUN & $4+$ \\
Brachiomonas & D. viridis & $4+$ \\
Chlamydomonas & BR-5 & - \\
Chlorococcum & MACC0054 & - \\
Chlorella & FLAE & - \\
Nannochloris & $7-15$ Nanno & - \\
Stichococcus & 126-01 & - \\
Stained spots' on cell wall, no uniform staining \\
\hline
\end{tabular}

An unusual cross-reaction with the more distantly related Chlorococcum (clone Chloro-1) was also noted (Table 7). This labeling appeared as several stained spots on the cell wall and was visually very different from the uniform labeling observed with all other cross reactions. Although the difference was obvious to the observer, most likely a flow cytometer would count the label as a simple positive.

Antiserum directed against the chrysophyte Pelagococcus subviridis (anti-PELA CL2) isolated from the North Pacific cross reacted with the Australian isolate CS-99, with 2 similarly pigmented coccoid clones from the Atlantic that likely are conspecific (Hooks et al. 1988, Shapiro et al. 1989) and weakly with another similarly pigmented coccoid clone IE11 (Table 8), but not with Pelagococcus clone H-314, nor with Aureococcus or any other chrysophytes tested. 
Table 8. Cross reactions within the Chrysophyceae with antiserum directed against Pelagococcus subviridis (PELA CL2) Reaction: see legend Table 3

\begin{tabular}{|c|c|c|}
\hline Clone & Designation & Reaction \\
\hline \multicolumn{3}{|l|}{ Pelagococcus } \\
\hline subviridis & PELA CL2 & $4+$ \\
\hline subviridis & CS-99 & $4+$ \\
\hline $\mathrm{sp}$ & $\mathrm{H}-314$ & - \\
\hline \multirow[t]{3}{*}{ Unidentified coccoid } & 1935 & $4+$ \\
\hline & IVR5 & $4+$ \\
\hline & IE11 & $1+/ 2+$ \\
\hline Unidentified flagellate & MC-1 & - \\
\hline Aureococcus anophagefferens & b.t.1 & - \\
\hline \multicolumn{3}{|l|}{ Ochromonas } \\
\hline stellaris & UW329 & - \\
\hline sp. & IC 1 & - \\
\hline Chrysamoeba sp. & IG5 & - \\
\hline
\end{tabular}

\section{DISCUSSION}

In most cases the serological recognition we observed was species-specific (to the extent that unambiguous identifications of species are available). Because many characteristics used to distinguish among the phytoplankton species are based on the flagella and their attachments, many of the coccoid eukaryotes have remained unclassified. The IF response may help in the definition of these species.

Species definition in phytoplankton is itself problematical since many forms may be primarily asexual, and even those with obligative sexual stages have the potential to establish large 'clones' in nature. In fact, the species unit is almost always assumed to be the morpho-species (but see Wood et al. 1987), and the correlation between morphological and genetic discontinuity is only assumed. Our results suggest there is at least enough genetic continuity, in cosmopolitan species, to permit recognition of surface antigens on clones from coastal waters on both sides of the Atlantic (Emiliania huxleyi and Micromonas pusilla), and from both the Atlantic and Pacific (Pelagococcus subviridis).

These results are consistent with similarities in electrophoretic phenotype (Murphy \& Guillard 1976), toxicity responses (Murphy \& Belastock 1980) and temperature responses (Brand et al. 1981) in the cosmopolitan centric diatom Thalassiosira pseudonana. Isolates from Long Island, New York (3H); Chincoteague, Virginia (C5); St. Croix, US Virgin Islands (STX-97); Bremen, FRG (W); and Perth, Australia (Swan-1) showed identical, or nearly identical, banding patterns and responses. In fact, cosmopolitan distributions may be recent. Emiliania huxleyi is a fairly recent species, having evolved late in the Pleistocene, about 200000 years ago (Tappan 1980). Nothing is known of the geological history of the delicate flagellate Micromonas pusilla Independent of the age of the morpho-species, races or successful genotypes may be of more recent origin, or distributed by shipping activity (especially during the last century)

Emiliania huxleyi cells can assume 3 morphological types: coccolith-bearing, naked, or scaled. The scaled form is motile and presumed haploid and alternates, during the life history, with the non-motile, presumably diploid form. The latter may be covered with coccoliths or naked. A 'naked' form lacks coccoliths and scales but is, none the less, covered by an organic pellicle presumably of pectin. The pellicle itself is covered, on its inner and outer surfaces, by membranes. The coccoliths contain an organic matrix of protein and polysaccharides and are bounded by a matrix membrane. Scales are composed of organic material, presumably protein and polysaccharides (Klaveness 1972, 1976. Westbroek et al. 1984). We generated antibodies to a naked form (BT-6), and tested the cross reactions of the resulting antiserum to itself, other naked forms, coccolith-bearing forms, and one scaled, motile form. All tested clones were recognized by the antiserum. This indicates the presence of a compound, peculiar to the species and produced throughout the life history, that is found in the matrix or matrix membranes of the scales, coccoliths and pellicle.

Techniques available for analysis of fragile components of natural assemblages include EM, HPLC, and the various fluorescence analyses. EM provides the greatest morphological detail for taxon identification, but analysis is slow and relatively costly. Also, preservation damage may bias population estimates in favor of more 'preservable' species. HPLC can provide evidence of taxa even when those taxa are no longer evident in preserved samples (Gieskes \& Kraay 1983), but cannot provide specific identifications, and cannot provide information on a cell-by-cell basis. Microspectrophotometry is still of limited value for identification of ultraplankton-sized cells and, like HPLC, cannot separate several major taxa (Iturriaga et al. 1987). The IF approach should allow identification of extremely small species, and cell-by-cell quantification of specific components in natural assemblages. The approach will provide an additional level of detail to single-cell fluorescence analysis as used in epifluorescence microscopy and flow cytometry, by adding a specific immunofluorescent signal to the catalog of available autofluorescent signal from chlorophyll and phycoerythrin. Our preliminary trials with flow cytometry, using FITC fluorescence of the IF label and the non-overlapping autofluorescence of chlorophyll as parameters, are encouraging. The obvious marriage of immunochemi- 
cal identification to flow cytometric analysis should lead to studies of temporal and spatial changes in dominance and diversity within the ultraphytoplankton community.

Acknowledgements. We thank Dr R. R. L. Guillard for editorial suggestions, L. Morris and K. Knowiton for technical assistance and M. C. Hernandez-Davis for manuscript preparation. Clones were obtained from the Provasoli-Guillard Center for the Culture of Marine Phytoplankton, Bigelow Laboratory, except that clone CS-99 was provided by Dr S. W Jeffrey and clone b.t. 1 by Dr E. M. Cosper. This material is based upon work supported by the National Science Foundation under Grants OCE-8710214 and OCE-8811999. The government has certain rights in this material. This is Bigelow Laboratory contribution no. 89023, and HIG contribution no. 2173 .

\section{LITERATURE CITED}

Brand, L. E., Murphy, L. S., Guillard, R. R. L., Lee, H.-t. (1981). Genetic variability and differentiation in the temperature niche component of the diatom Thalassiosira pseudonana. Mar Biol. 62: 103-110

Butcher, R. W (1959). An introductory account of the smaller algae of British coastal waters. Part I: Introduction and Chlorophyceae. Fisheries Investigations Series IV Her Majesty's Stationery Office, London

Campbell. L. (1988). Identification of marine chroococcoid cyanobacteria by immunofluorescence. In: Yentsch, C. M., Mague, F. C., Horan, P. K. (eds.) Immunochemical approaches to coastal, estuarine and oceanographic questions. Lecture notes on coastal and estuarine studies. Springer Verlag, New York, p. 208-229

Campbell, L., Carpenter, E. J., Lacono, V L. (1983). Identification and enumeration of marine chroococcoid cyanobacteria by immunofluorescence. Appl. envirl. Microbiol. 46 $553-559$

Campbell, L., Shapiro, L. P., Haugen, E. M., Morris, L. (1989). Immunochemical approaches to the identification of the ultraplankton: assets and limitations. In: Cosper, E. M., Carpenter, E. J., Bricelj, M. (eds.) Novel phytoplankton blooms. Lecture notes on coastal and estuarine studies. Springer Verlag, Berlin (in press)

Davis, P. G., Caron, D. A., Johnson, P. W., Sieburth, J. McN (1985). Phototrophic and apochlorotic components of picoplankton and nanoplankton in the North Atlantic: geographical, vertical, seasonal and diel distributions. Mar. Ecol. Prog. Ser. 21: 15-26

Gieskes, W. W., Kraay, G. W. (1983). Dominance of Cryptophyceae during the phytoplankton spring bloom in the central North Sea detected by HPLC analysis of pigments Mar Biol. 75: 179-185

Hobbie, J. E., Daley, R. J., Jasper, S. (1977). Use of nuclepore filters for counting bacteria by fluorescence microscopy. Appl envirl. Microbiol. 33: 1225-1228

Hooks, C. E., Bidigare, R. R., Keller, M. D., Guillard, R. R. L. (1988). Coccold eukaryotic marine ultraplankters with four different HPLC pigment signatures. J. Phycol. 24: 571-580

This article was presented by Professor T Berman, Tiberias, Israel
Iturriaga, R., Mitchell, B. G., Kiefer, D A (1988). Microphotometric analysis of individual particle absorption spectra. Lumnol. Oceanogr. 33: 128-135

Johnson, P. W. Sieburth, J. M[CN. (1979). Chroococcoid cyanobacteria in the sea: a ubiquitous and diverse phototrophic biomass. Limnol. Oceanogr 24: 928-935

Johnson, P. W. Sieburth, J. McN. (1982). In situ morphology and occurrence of eucaryotic phototrophs of bacterial size in the picoplankton of estuarine and oceanic waters. J. Phycol. 18: 318-327

Klaveness, D. (1972). Coccolithus huxleyi (Lohmann) Kamptner I. Morphological investigations of the vegetative cell and the process of coccolith formation. Protistologica VIII: $335-346$

Klaveness, D. (1976). Emiliania huxleyi (Lohmann) Hay \& Mohler. III. Mineral deposition and the origin of the matrix during coccolith formation. Protistologica XII: 217-224

Mattox, K. R., Stewart, K. D. (1984). Classification of the green algae: a concept based on comparative cytology. In: Irvine, D. E. G., John, D. M. (eds.) Systematics of the green algae. Academic Press, Orlando, Florida, p. 29-72

Murphy, L. S., Belastock, R. A. (1980). The effect of environmental origin on the response of marine diatoms to chemical stress. Limnol. Oceanogr. 25: 160-165

Murphy, L. S., Guillard, R. R. L. (1976). Biochemical taxonomy of marine phytoplankton by electrophoresis of enzymes. I The centric diatoms Thalassiosira pseudonana and $T$ fluviatilis. J. Phycol. 12: 9-13

Murphy, L. S. Haugen, E. M. (1985). The distribution and abundance of phototrophic ultraplankton in the North Atlantic. Limnol, Oceanogr. 30: 47-58

Shapiro, L. P., Guillard, R. R. L. (1986). Physiology and ecology of marine eukaryotic ultraplankton. In: Platt, T., Li, W K. W (eds.) Photosynthetic picoplankton. Can. J. Fish. aquat. Sci. 214: 371-389

Shapiro, L. P., Haugen, E. M., Keller, M. D., Bidigare, R. R., Campbell, L., Guillard, R. R. L. (1989). Taxonomic affinities of marine coccoid ultraphytoplankton: a comparison of immunochemical surface antigen cross-reactions and HPLC chloroplast pigment signatures. J. Phycol. 25: in press

Stockner, J. G., Antia, N. J. (1986). Algal picoplankton from marine and freshwater systems: a multidisciplinary perspective. Can. J. Fish, aquat. Sci. 43: 2472-2503

Tappan. H. (1980). The paleobiology of plant protists. W. H. Freeman and Company. San Francisco, p. 761-769

Thomsen, H. A. (1986). A survey of the smallest eucaryotic organisms of the marine phytoplankton. In: Platt, T., Li, W K. W (eds.) Photosynthetic picopiankton. Can. J. Fish. aquat. Sci. $214: 121-158$

Waterbury, J. B., Watson, S. W., Guillard, R. R. L., Brand, L. E (1979). Widespread occurrence of a uniceliular marine planktonic cyanobacterium. Nature, Lond. 277. 293-294

Westbroek, P., de Jong, E. W., van der Wal, P., Borman, A. H., de Vrind, J. P. M., Kok, D., de Bruijn, W. C., Parker, S. B. (1984). Mechanism of calcification in the marine alga Emiliania huxleyi. Phil. Trans. R. Soc. (Ser. B) 304:435-444

Wood, A. M. Lande, R., Fryzell. G. A. (1987). Quantitative genetic analysis of morphological variation in an Antarctic diatom grown at two light intensities. J. Phycol. 23: 42-54

Manuscript first received: Aprl 9, 1989

Revised version accepted: July 26, 1989 